\title{
The Effect of Vitamin B Complex on Survival, Growth and Stress Resistance of Nile Tilapia (Oreochromis niloticus) Larvae
}

\author{
Nurfadilah1, Ruqayyah Jamaluddin ${ }^{1}$, Muhammad Yusri Karim² \\ ${ }^{1)}$ Faculty of Fisheries, Cokroaminoto University, Makassar, Indonesia \\ ${ }^{2)}$ Faculty of Marine Science and Fisheries, Hasanuddin University, Makassar, Indonesia \\ DOI: 10.29322/IJSRP.11.11.2021.p11929 \\ http://dx.doi.org/10.29322/IJSRP.11.11.2021.p11929
}

\begin{abstract}
Nile tilapia (Oreochromis niloticus) is one of the important economic value fishery commodities and has been cultivated commercially. The main problem experienced is the low seed production through hatchery units due to the low survival rate, especially in the larval stage. This research was conducted at CV. Aquaculture Lestari, Makassar aims to evaluate the effect of vitamin B complex on the survival, growth, and stress resistance of nile tilapia (O. niloticus) larvae. The study used a container in the form of a black plastic basin with a capacity of $40 \mathrm{~L}$ which would be filled with $30 \mathrm{~L}$ of media water. The test animals used were 3-day old nile tilapia larvae which were kept for 30 days. The feed used is artificial feed in the form of powder and pellets. The study was designed using a completely randomized design consisting of 4 doses of vitamin B complex treatment with 3 replications each. The four doses are $0,50,100$, and $150 \mathrm{mg} / \mathrm{L}$. The analysis of variance showed that the supplementation of vitamin B complex had a very significant effect $(p<0.01)$ on the survival, growth, and level of stress resistance (CSI) of nile tilapia larvae. The highest survival rate and growth rate, and the lowest CSI of nile tilapia larvae were produced at a dose of $50 \mathrm{mg} / \mathrm{L}$ i.e., 75.44\%; and 12.26\%/day; and 66.00, respectively, while the lowest survival rate and growth rate as well as the highest CSI were obtained at a dose of $0 \mathrm{mg} / \mathrm{L}$, i.e., $48.11 \%$; and $8.68 \% /$ day; and 90.67 , respectively.
\end{abstract}

Index Terms- nile tilapia, growth, stress resistance, survival rate, vitamin B complex

\section{INTRODUCTION}

$\mathrm{N}$ ile tilapia is one type of fishery commodity with important economic value. This species of fish is preferred by the public because of its delicious taste and high nutritional value (Ansah et al., 2014; Mapenzi and Mmochi, 2016; Barosso et al., 2019). Nile tilapia has several advantages, including: its fast growth rate and can reach a much larger body weight with a fairly high level of productivity. From the aspect of productivity, nile tilapia is very potential and productive if it is cultivated in various fields, not only in ponds but also in highland ponds (Watanabe $e t$ al., 2002; Tran et al., 2021).

The main problem in the development of nile tilapia is the availability of seeds continuously and of good quality. Currently, efforts are being made to produce nile tilapia seeds through hatcheries. However, the main problem faced in hatchery efforts is the low survival rate, especially in the larval phase (Pandit et al., 2017). The cause of the low survival rate in larvae is low feed quality and a less than optimal rearing environment. According to Suleman and Fotedar (2017) the larval phase is the most critical phase in the fish life cycle. After hatching, the life of the larvae is completely dependent on the source of food or energy reserves that have been prepared by the mother. The quality of energy reserves is very influential on the life and development of larvae. Poor feed quality causes disturbances in larval development, larvae are easily stressed and can even cause death (Das et al., 2012).

One of the efforts to overcome the problem of low survival in nile tilapia larvae is through improving feed nutrition. One of the nutrients needed by fish larvae is vitamins. Vitamins are organic nutrients that have various essential functions in metabolic processes (Lall and Kaushik, 2021). Although it is needed in small quantities, it is no less important to meet the nutritional needs of fish (Byrd et al., 2020). Vitamin B complex has a function as a coenzyme and precursor in metabolic processes. Vitamin B complex plays a role in good metabolic processes in cultivars so that the energy possessed can be used in a good growth process and will have an impact on survival within a certain time (Hansen et al., 2015). Vitamin B complex is also thought to play a role in the rate of daily weight gain of fish. The absence of vitamin input can affect the reduced feed intake by fish, thereby reducing the intake of the amount of nutrients needed for maximum fish body growth (Li et al., 2016). Research on the use of vitamin B complex has been carried out on juvenile Blunt Snout Breammun (Li et al., 2016), milkfish larvae (Salsabila et al., 2019). The results of these studies prove that the administration of vitamin B complex can increase the survival and growth of some fish larvae. However, the role of vitamin B complex in nile tilapia larvae is not known for certain.

This study was aimed to evaluate the effect of vitamin B complex on survival, growth rate, and stress resistance level of nile tilapia (O. niloticus) larvae.

\section{RESEARCH METHOD}

This research was carried out by CV. Aquaculture Lestari, Makassar. The research uses a container in the form of a 
black plastic basin with a capacity of $40 \mathrm{~L}$ which will be filled with $30 \mathrm{~L}$ of media water. These containers are equipped with aeration equipment. The media water used is freshwater sourced from the Local Water Company (aka PDAM).

The test animals used were 3 day old nila tilapia larvae which were reared for 30 days. The larvae were obtained from CV Aquaculture Lestari, Makassar. Prior to stocking, the larvae were weighed using a digital scale with an accuracy of $0.01 \mathrm{~g}$.

The feed used is artificial feed in the form of powder and pellets. Feeding started on days 1 to 14 using MS Prima feed PF 0 , and entering the 15th day until the end of the maintenance was given MS Prima Feed PF 500. The dose of feed given was 5\% with a frequency of feeding 3 times a day at 08.00 morning, 1:00 p.m. and 5:00 p.m.

The administration of vitamin B complex is done once a day according to the treatment dose. Giving is done in the morning after the water change. Water changes are carried out every day as much as $20 \%$ of the volume of media water.

At the end of the study, harvesting was carried out by counting the number of live nile tilapia larvae and re-weighing the weight of the larvae. Weighing was done using a digital scale with an accuracy of $0.01 \mathrm{~g}$.

The study was designed using a completely randomized design consisting of 4 treatments with 3 replications each, so that in this study there were 12 experimental units. The four doses of vitamin B-complex were 0, 50, 100, and $150 \mathrm{mg} / \mathrm{L}$. Placement of research containers was done randomly.

The parameters observed in this study were as follows:

\section{a. Survival rate}

Tilapia larvae survival was calculated using the following formula:

$\mathrm{S}=\left(\mathbf{N}_{\mathrm{t}} / \mathbf{N}_{\mathbf{o}}\right) \times 100$

Where: $\mathrm{S}$ is nile tilapia larvae survival $(\%), \mathrm{N}_{\mathrm{t}}$ is number of live nile tilapia larvae at the end of the study, $\mathrm{N}_{\mathrm{o}}$ is Number of nile tilapia larvae at the beginning of the study.

\section{b. Growth rate}

The growth rate of nile tilapia larvae was calculated using the formula

SGR $=100 \times\left(\ln W_{t} / W_{0}\right) / t$

Where: SGR is daily specific growth rate (\%/day), $\mathrm{W}_{\mathrm{t}}$ is average weight of nile tilapia larvae at the end of the study $(\mathrm{mg}), \mathrm{W}_{\mathrm{o}}$ is average weight of nile tilapia larvae at the beginning of the study (mg)

\section{c. Stress Resistance}

Stress resistance test was conducted to see the physiological condition of nile tilapia larvae after being given Vitamin B-complex. Stress measurement was carried out at the end of the study by taking 10 tilapia larvae randomly from the rearing medium and put into a $1 \mathrm{~L}$ volume glass beaker filled with water with high salinity $(25 \mathrm{ppt})$. The number of stressed white snapper larvae was observed at every 5-minute interval during a 1-hour period.

Assessment of nile tilapia larvae resistance was carried out qualitatively based on the behavioral response or abnormal movement of tested tilapia larvae to death during the stress experiment. The indications of nile tilapia larvae experiencing stress in the form of abnormal (up and down movement) and spinning until they die.

Evaluation of larval stress resistance was calculated using the Cumulative Stress Index (CSI) formula from the Ress et al. (1994) as follows:

CSI $=$ D5 + D10 + D15 + ... + D60

Where: CSI is cumulative stress index, D is number of stressed nile tilapia larvae at a certain minute.

The higher the CSI value, the lower the larval resistance level, and vice versa the lower the CSI value the higher the larval resistance level.

\section{d. Water Quality Parameters}

During the experiment, several water quality parameters were measured for the rearing media for nile fish larvae. The parameters measured were temperature, $\mathrm{pH}$, dissolved oxygen, and ammonia. Temperature was measured using a thermometer, dissolved oxygen with a DO meter, $\mathrm{pH}$ with a $\mathrm{pH}$ meter and ammonia using a spectrophotometer. Measurements of temperature, $\mathrm{pH}$, and dissolved oxygen were carried out twice a day at 6 am and $5 \mathrm{pm}$. Ammonia was measured three times during the study, namely at the beginning, middle, and end of the study.

The data obtained in the form of survival rate, growth rate, and stress resistance were analyzed using analysis of variance (ANOVA). If there is a significant effect, it is continued with the W-Tuckey test. As a tool for carrying out the statistical test, the SPSS version 22.0 computer software package was used. The water quality parameters were analyzed descriptively based on the viability of nile tilapia larvae.

\section{RESULTS AND DISCUSSION}

\section{a. Results}

Survival, Growth, and Stress Resistance of Nile Tilapia Larvae

The average survival rate, growth rate, and stress resistance level (CSI) of nile tilapia larvae given various doses of vitamin B complex are presented in Table 1.

Table 1. Average survival, growth rate, and stress resistance of nile tilapia larvae in various doses of vitamin B complex

\begin{tabular}{|c|c|c|c|}
\hline $\begin{array}{l}\text { Dose of Vitamin } \\
\text { Complex }(\mathrm{mg} / \mathrm{L})\end{array}$ & $\begin{array}{l}\text { Survival rate } \\
(\%)\end{array}$ & $\begin{array}{l}\text { Growth } \\
\text { (\%/hari) }\end{array}$ & CSI \\
\hline 0 & $48.11 \pm 1.58^{\mathrm{d}}$ & $8.68 \pm 0.07^{\mathrm{c}}$ & $90.67 \pm 4.16^{\mathrm{a}}$ \\
\hline 50 & $75.44 \pm 0.51^{\mathrm{a}}$ & $12.26 \pm 0.53^{\mathrm{a}}$ & $66.00 \pm 3.60^{c}$ \\
\hline 100 & $62.56 \pm 0.84^{\mathrm{b}}$ & $9.80 \pm 0.12^{\mathrm{b}}$ & $75.67 \pm 2.08^{\mathrm{b}}$ \\
\hline 150 & $54.11 \pm 5.03^{\mathrm{c}}$ & $9.05 \pm 0.16^{\mathrm{c}}$ & $79.33 \pm 0.58^{b}$ \\
\hline
\end{tabular}

Note: different letters in the same column indicate significant differences among

This publication is licensed under Creative Commons Attribution CC BY. 
treatments at the $5 \%$ level $(\mathrm{p}<0.05)$

The results of the analysis of variance showed that the administration of B-complex vitamins had a very significant effect ( $\mathrm{p}<0.01$ ) on survival, growth rate, and stress resistance (CSI) of nile tilapia larvae. Based on Table 1, the high survival rate and growth rate of nile tilapia larvae were produced at a dose of 50 $\mathrm{mg} / \mathrm{L}$ and the lowest at $0 \mathrm{mg} / \mathrm{L}$. Meanwhile, the lowest CSI value was obtained at a dose of $50 \mathrm{mg} / \mathrm{L}$ and the highest at $0 \mathrm{mg} / \mathrm{L}$.
The relationship between vitamin B-complex dose and survival rate $\left(\mathrm{Y}_{1}\right)$, growth rate $\left(\mathrm{Y}_{2}\right)$, and $\mathrm{CSI}\left(\mathrm{Y}_{3}\right)$ of nile tilapia larvae with quadratic pattern with the equation $\mathrm{Y} 1=50.293+0.5426 \mathrm{x}-$ $0.0035 \mathrm{x} 2\left(\mathrm{R}^{2}=0.74\right) ; \mathrm{Y} 2=9.0637+0.0623 \mathrm{x}-0.0004 \times 2(\mathrm{R} 2=$ $6.00)$, and $\mathrm{Y} 3=88.650+0.4737 \mathrm{x}-0.0028 \times 2\left(\mathrm{R}^{2}=0.69\right)($ Figures $1,2$ and 3$)$.

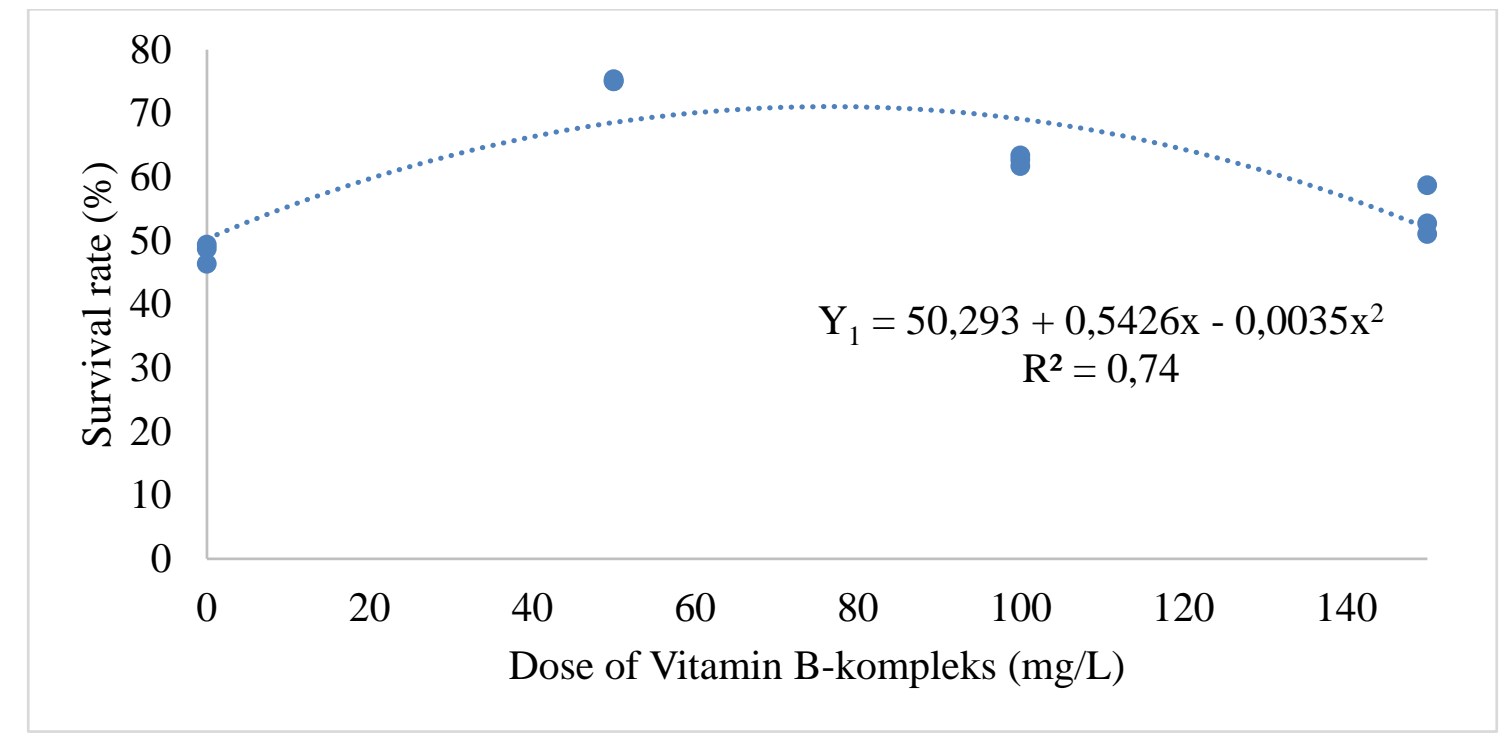

Figure 1. Relationship between B-complex vitamin dose and survival of nile tilapia larvae

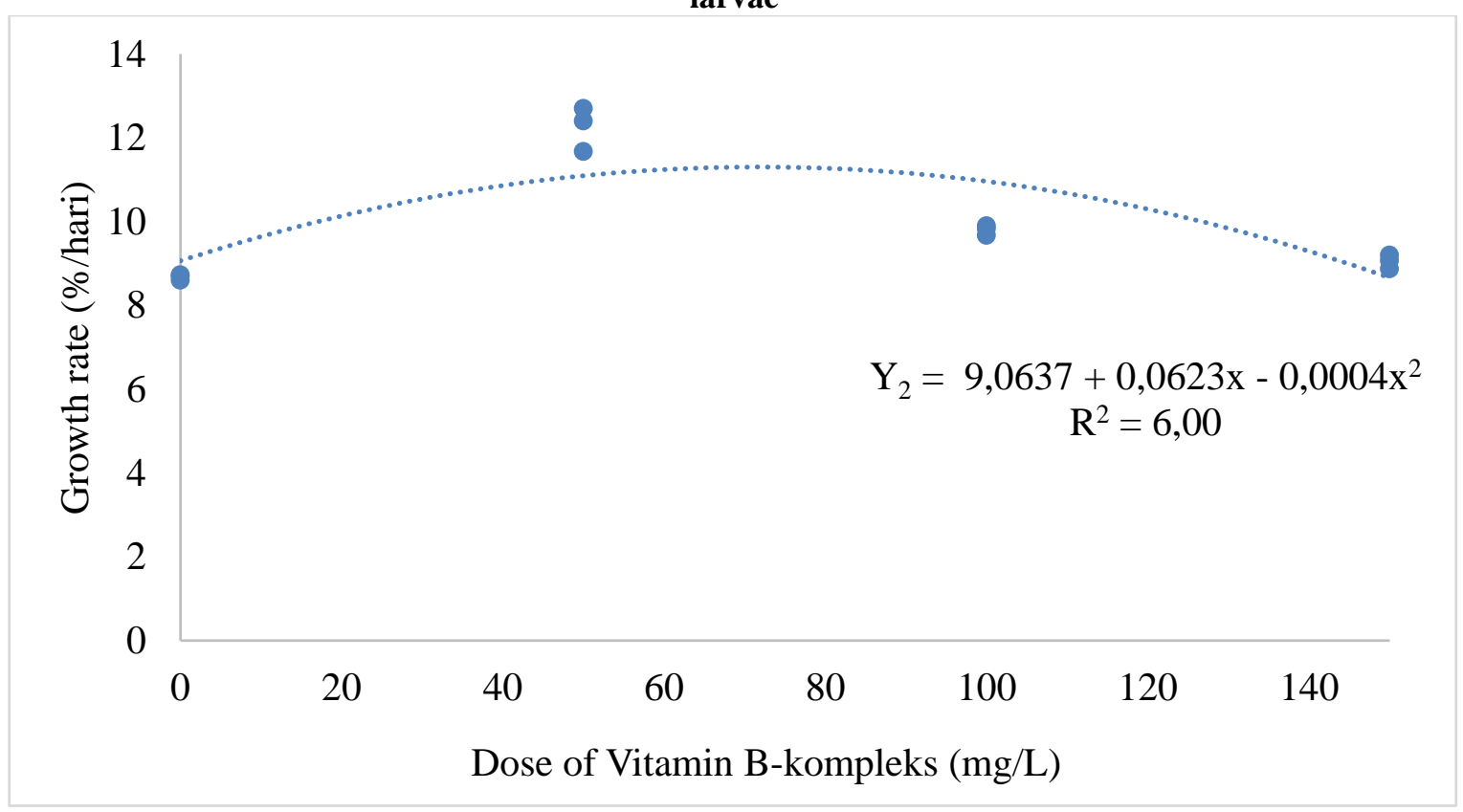

Figure 1. Relationship between B-complex vitamin dose and survival of nile tilapia larvae 


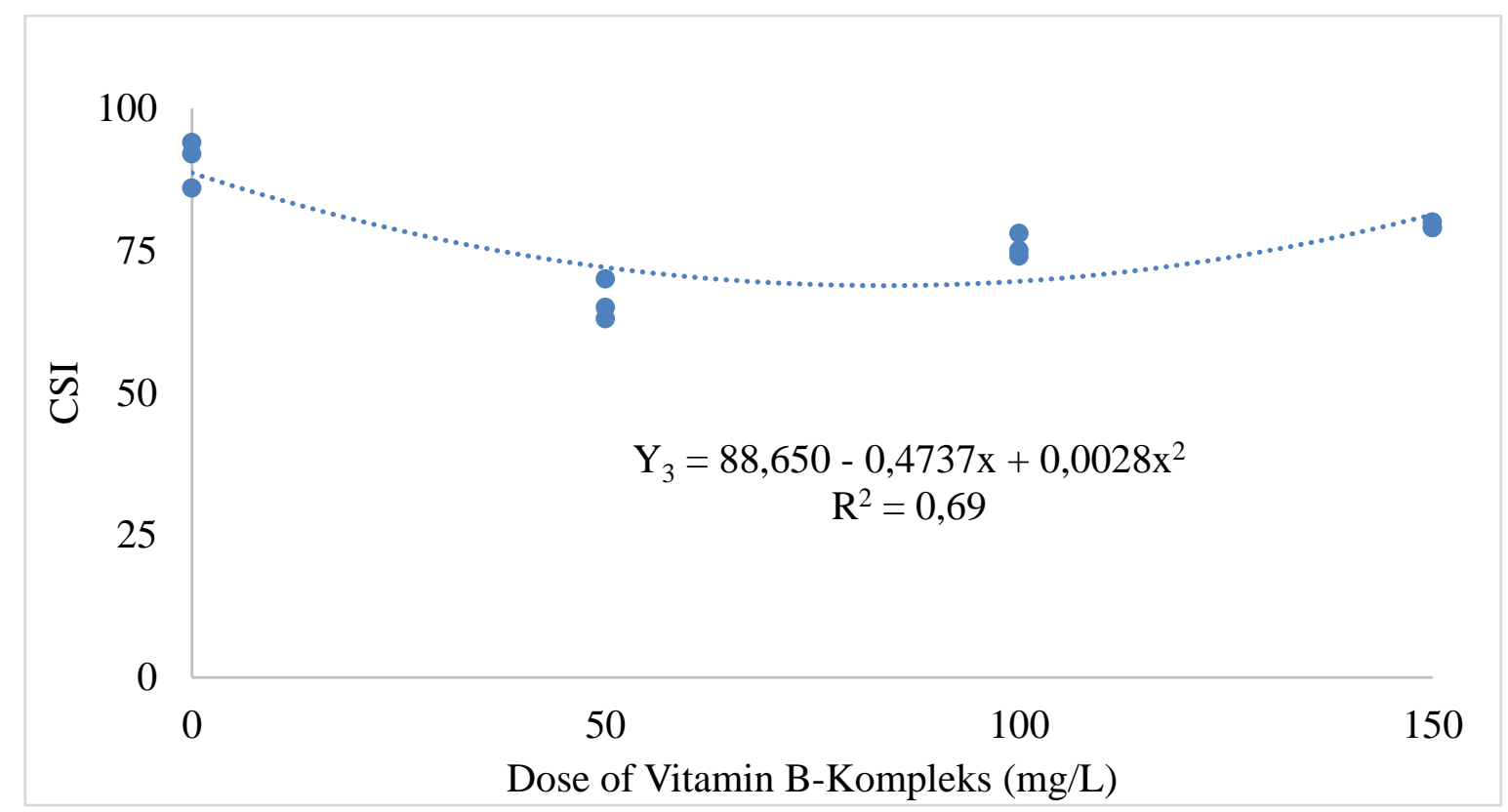

Figure 3. Relationship between B-complex vitamin dose and CSI of nile tilapia Larvae

Based on the regression equation above, it can be predicted that the optimum (op) dose for survival $\left(\mathrm{Y}_{\mathrm{op} 1}\right)$, growth rate $\left(\mathrm{Y}_{\mathrm{op} 2}\right)$ and CSI ( $\left(\mathrm{Y}_{\mathrm{op} 3}\right)$ of tilapia larvae can be achieved at doses of 77.43 $\left(\mathrm{Yo}_{\mathrm{p} 1}\right), 77.87\left(\mathrm{Y}_{\mathrm{op} 2}\right)$, respectively. , and $84.59 \mathrm{mg} / \mathrm{L}\left(\mathrm{Y}_{\mathrm{op} 3}\right)$.

\section{Water Quality Parameters}

During the research, measurements of several water quality parameters of tilapia larvae rearing media were carried out including: temperature, $\mathrm{pH}$, dissolved oxygen, and ammonia. The range of parameter values is presented in Table 2.

Table 2. Range of water quality parameter values for tilapia larvae rearing media

\begin{tabular}{ll}
\hline Parameters & Range Value \\
\hline Temperature & $28-30$ \\
$\mathrm{pH}$ & $7.1-7.6$ \\
Dissolved Oxygen (ppm) & $4.2-5.1$ \\
Ammonia (ppm) & $0.02-0.09$ \\
\hline
\end{tabular}

\section{b. Discussion}

Based on Table 1, the survival rate, growth rate and the highest level of stress resistance (lowest CSI) of nile tilapia larvae were produced at a dose of $50 \mathrm{mg} / \mathrm{L}$ while the lowest (highest CSI) was at $0 \mathrm{mg} / \mathrm{L}$. Nile tilapia larvae that were given vitamin Bcomplex at a dose of $50 \mathrm{mg} / \mathrm{L}$ had a high resistance to stress so that the larvae could exist to survive and grow. If the larvae experience stress, the adrenal glands will produce high levels of the hormone cortisol, which is a stress-causing hormone (Sadoul and Giffroy, 2019). In these conditions, when given vitamin B complex, especially vitamin B5, which plays a role in improving the function of the adrenal glands that manage stress (Singh, 2016). If stress can be overcome, the body's work system in fish larvae will return to normal and larvae can exist to live and grow (Rehman et al., 2017). Vitamin B complex has an important role in energy metabolism. According to Sherwood (2014), the reshuffle of carbohydrates into glucose will produce energy and the energy produced can suppress the release of the ACTH hormone, which is a stress-causing hormone. With the availability of energy, in addition to increasing larval resistance to stress, it also increases survival and growth.

The low survival rate, growth rate, and stress resistance level of nile tilapia larvae at a dose of $0 \mathrm{mg} / \mathrm{L}$ were due to the absence of absorption of B-complex vitamins from the media. In general, the B-complex vitamins (thiamine, riboflavin, niacin, pantothenic acid, pyridoxine, biotin, folate, and cyanocobalamin) have unique coenzyme functions in cellular metabolism, and play an important role in energy-producing metabolic pathways for carbohydrates, fats and proteins and in maintaining nervous system function (Dai and Koh, 2015; NRC, 2011). This was stated by several researchers about the use of B vitamins such as McLean and Hannan (2007); Swart et al. (2013); Clarke et al. (2014). Thiamine (vitamin B1) in its active form is an important cofactor for enzymes involved in carbohydrate, lipid and amino acid metabolism, and in the synthesis of neurotransmitters. It is also important for a number of enzymatic processes in energy production, including decarboxylation and transketolase reactions that occur in the cell cytoplasm (Dai and Koh, 2015; Halver and Hardy, 2002; NRC, 2011). Pyridoxin (vitamin B6) in animal 
tissues is converted to the active form pyridoxal phosphate, involved as a cofactor in enzymatic reactions involving amino acids, such as transamination, decarboxylation and dehydration. It is also involved in the synthesis of collagen, nucleic acids, porphyrins, neurotransmitters, glycogen catabolism, fat metabolism (especially essential fats). acid), messenger RNA synthesis and in immune system function (Dai and Koh, 2015; Halver and Hardy, 2002; NRC, 2011). Vitamin B6 acts as a cofactor for lysyl oxidase which is essential for the enzymatic action of lysyl oxidase in collagen crosslinking. In several studies the effects of additional vitamins (thiamine, pyridoxine and cyanocobalamin) both singly and in combination were tested on premium commercial micro feeds, which was not expected to be vitamin B restriction. vitamin B1), pyridoxine (vitamin B6) and 5fold cyanocobalamin (vitamin B12) can provide additional benefits to the performance of bone growth and development (Pinto et al., 2018). Previous studies on various fish species tended to show an increase in growth with an increase in dietary B vitamins. This was the case for vitamin B1 in juvenile Schizothorax, a species of stingray found in China (Xiang et al., 2016), in which the increase in growth was almost unchanged with levels above $21.5 \mathrm{mg} / \mathrm{kg}$ feed. Similarly, administration of vitamin B6 more than $5 \mathrm{mg} / \mathrm{kg}$ and vitamin B12 more than $0.051 \mathrm{mg} / \mathrm{kg}$ did not result in increased performance in juvenile carp (He et al., 2019) and fingerling bream bream (Li et al., 2016).

The addition of vitamin B complex exceeding $50 \mathrm{mg} / \mathrm{L}$ will reduce the survival, growth, and stress resistance of nile tilapia larvae. This is thought to have exceeded the needs of tilapia larvae. According to Elango et al. (2015) although vitamins are needed by humans to meet nutritional needs, excess vitamins can have a negative effect. The accumulation of this vitamin under certain circumstances can lead to toxic or toxic conditions (hypervitaminosis).

The results of measurements of several water quality parameters of the maintenance media showed that the temperature values of the maintenance media were $28-30 \mathrm{oC}, \mathrm{pH} 7.1-7.6$, dissolved oxygen 4.2-5.1 ppm, and ammonia 0.02-0.09 ppm. The range of water quality parameter values is still in a reasonable range for tilapia larvae. According to Alfia et al. (2013) and Siniwoko (2013) that a good temperature for tilapia ranges from 25-30oC, pH 7.0-7.5 (Amri and Khairuman, 2013; Siniwoko, 2013), dissolved oxygen ranges from 4-7 ppm, and ammonia $<0.1$ ppm water (Amri and Khairuman, 2013).

\section{CONCLUSION}

Based on the results of this study, it can be concluded that the administration of vitamin B-complex at a dose of $50 \mathrm{mg} / \mathrm{L}$ resulted in better survival, growth rate, and stress resistance in nile tilapia larvae.

\section{REFERENCES}

[1] Alfia RA., Arini E., Elfitasari T. 2013. Effect of Different Density on Survival and Growth of Tilapia (Oreochromis niloticus) in Recirculation System with Bioball Filter. Journal of Aquaculture Management and Technology, 2 (3): 86-93. (In Indonesia).

[2] Amri, K. dan H. Khairuman. 2013. Nile Tilapia Cultivation. PT. Agro Media Pustaka, Jakarta. (In Indonesia).
[3] Ansah, Y. B., E. A. Frimpong, and E. M. Hallerman. 2014. GeneticallyImproved Tilapia Strains in Africa: Potential Benefits and Negative Impacts. Sustainability, 6: 3697-3721.

[4] Barosso, R.M., A.E.P. Munoz, and J. Cai. 2019. Social and Economic Perpormanceof Tilapia Farming in Brazil. FAO Fisheries and Aquaculture Circular No. 1181. Rome, Italy

[5] Byrd, K.A., S. H. Thilsted, and K. J. Fiorella. 2020. Fish nutrient Composition: A Review of Global Data From Poorly Assessed Inland And Marine Species. Public Health Nutrition, 24(3), 476-486.

[6] Clarke M, Ward M, Strain JJ, Hoey L, Dickey W, McNulty H. 2014. Bvitamins and bone in health and disease: the current evidence. Proceedings of the Nutrition Society, 73: 330-339.

[7] Dai, Z. and W-P Koh. 2015. B-Vitamins and Bone Health-A Review of the Current Evidence. Nutrients 7: 3322-3346.

[8] Das, P., S. C. Mandal, S. K. Bhagabati, M. S. Akhtar. and S. K. Singh. 2017. Important Live Food Organisms and Their Role In Aquaculture. Frontiers In Aquaculture: $69-86$.

[9] Elango, E., D. D. Venkataraman, S. Venkata Rao and V.S. R. Kiran. 2015. Hypervitaminosis. International Journal of Biomedical Research, 6(03): 151154.

[10] Halver, J. and R. Hardy. 2002. Fish Nutrition. Third edition. Academic Press, London-New York

[11] Hansen, A. C., Waagbø, R., Hemre, G. I. 2015. New B Vitamin Recommendations in Fish When Fed Plant - Based Diets. Aquaculture Nutrition, 21: 507-527.

[12] He W, Zhou X-Q, Feng L, Jiang J, Liu Y. 2009. Dietary pyridoxine requirement of juvenile Jian carp (Cyprinus carpio var. Jian). Aquaculture Nutrition 15: 402-408.

[13] Lall, S.P. and S. J. Kaushik. 2021. Nutrition and Metabolism of Minerals in Fish. Animals, 11, 2711.https://doi.org/10.3390/ani11092711.

[14] Li, X.F., F. Wang, Y. Qian, and J. Ghuan-Zeng. 2016. Dietary vitamin B12 requirement of fingerling blunt snout bream Megalobrama amblycephala determined by growth performance, digestive and absorptive capability and status of the GH-IGF-I axis. Aquaculture, 464: 647-653.

[15] Mapenzi LL, Mmochi AJ (2016) Role of Salinity on Growth Performance of Oreochromis niloticus $\ngtr$ and Oreochromis urolepis urolepis $\widehat{ }{ }^{\lambda}$ Hybrids. J Aquac Res Development 7: 2-5.

[16] McLean RR, Hannan MT. 2007. B vitamins, homocysteine, and bone disease: Epidemiology and pathophysiology. Current Osteoporosis Reports 5: $112-119$.

[17] NRC (National Research Council). 2011. Vitamins. In Nutrient Requirements of Fish and Shrimp The National Academies Press: Washington, DC; $186-220$.

[18] Pandit, N. P., R. Wagle, and R. Ranjan. 2017. Alternative Artificial Incubation System For Intensive Fry Production of Nile tilapia (Oreochromis niloticus). International Journal of Fisheries and Aquatic Studies, 5(4): 425429.

[19] Rehman, S., A. H. Gora, I. Ahmad, and S. I. Rasool. 2017. Stress in Aquaculture Hatcheries: Source, Impact and Mitigation Int.J.Curr.Microbiol.App.Sci., 6 (10): 3030-3045.

[20] Ress, J. F., K. Cure, S. Piyatiratitivorakul, P. Sorgeloos, and P. Menasveta, 1994. Highly Unsaturated Fatty Acid Requirements of Penaeus monodon Postlarvae : An Exprimental Approach Based on Artemia Enrichment. Aquaculture, 122 : 193-207.

[21] Sadoul, B. and B. Geffroy. 2019. Measuring Cortisol, The Major Stress Hormone in Fishes. Journal of Fish Biology, 94:540-555.

[22] Salsabila, G., Suminto, and A. N. Ristiawan. 2019. Effect of Enrichment of Brachionus rotundiformis with Different Doses of Vitamins (B1, B6, B12 and Vitamin C) in Feeding Regimes on Survival and Growth of Milkfish (Chanos chanos) Larvae. Journal of Tropical Aquaculture Science, 3(2) : 1120. (In Indonesia).

[23] Singh, K. 2016. Nutrient and Stress Management. Journal of Nutrition \& Food Sciences, Volume 6, Issue 4, 1000528. ISSN: 2155-9600 JNFS, an open access Journal.

[24] Siniwoko, D. E. 2013. Nile Tilapia Fish Cultivation and Business. Dafa Publishing, Surabaya. (In Indonesia).

[25] Sulaeman and R. Fotedar. 2017. Yolk Utilization And Growth During the Early Larval Life of the Silver Perch, Bidyanus bidyanus (Mitchell, 1838). Int Aquat Res. DOI 10.1007/s40071-017-0160-7. 
[26] Swart, K.M.A., N. M. Aan Schoor, and P. Lips. 2013. Vitamin B12, Folic Acid, and Bone. Current Osteoporosis Reports., 11: 213-218.

[27] Tran, N., K. M. Shikuku, C. M. Rossignoli, B.K. Barman, K. C. Chiong, M. S. Ali, and J. A. H. Benzie. 2021. Growth, Yield and Profitability of Genetically Improved Farmed Tilapia (GIFT) and non-GIFT strains in Bangladesh. Aquaculture, 536: 1-11.

[28] Watanabe, W.O., T. M. Losordo, K. Ftzimmons, and F. Handley. 2002. Tilapia Production Systems in the Americas: Technological Advances, Trends, and Challenges. Reviews in Fisheries Science, 10(3\&4): 465-498.

[29] Xiang X, Zhou X-Q, Chen G-F, Wu P, Zheng Z-L. 2016. Effect of graded levels of dietary thiamine on the growth performance, body composition and haematobiochemical parameters of juvenile Sclizothorax prenanti. Aquaculture Nutrition, 22: 691-697.

\section{AUTHORS}

First Author - Nurfadilah, Faculty of Fisheries, Cokroaminoto University, Makassar, Indonesia

Second Author - Ruqayyah Jamaluddin, Faculty of Fisheries, Cokroaminoto University, Makassar, Indonesia

Third Author - Muhammad Yusri Karim, Faculty of Marine Science and Fisheries, Hasanuddin University, Makassar, Indonesia

Correspondence Author Email: nurfadilah.sakkirang@gmail.com 